\title{
Enhancing Sustainability in Forestry Using Material Flow Cost Accounting
}

\author{
Konstantinos G. Papaspyropoulos ${ }^{1 *}$, Dimitrios Karamanolis ${ }^{1}$, Christos K. Sokos ${ }^{2}$, Periklis K. Birtsas ${ }^{3}$ \\ ${ }^{1}$ Laboratory of Forest Economics, Department of Forestry and Natural Environment, Aristotle University of Thessaloniki, Thessaloniki, \\ Greece \\ ${ }^{2}$ Research Division, Hunting Federation of Macedonia and Thrace, Thessaloniki, Greece \\ ${ }^{3}$ Laboratory of Wildlife, Department of Forestry and Natural Environment Management, Technological Education Institute of Thessaly, \\ Karditsa, Greece \\ Email: *kodafype@for.auth.gr
}

How to cite this paper: Papaspyropoulos, K. G., Karamanolis, D., Sokos, C. K., \& Birtsas, P. K. (2016). Enhancing Sustainability in Forestry Using Material Flow Cost Accounting. Open Journal of Forestry, 6, 324-336. http://dx.doi.org/10.4236/ojf.2016.65026

Received: June 2, 2016

Accepted: August 8, 2016

Published: August 11, 2016

Copyright $\odot 2016$ by authors and Scientific Research Publishing Inc. This work is licensed under the Creative Commons Attribution International License (CC BY 4.0).

http://creativecommons.org/licenses/by/4.0/

\begin{abstract}
Forestry is an applied science related to the sustainable management of natural resources. Many scientific disciplines influence forest science including ecology, economics and other social sciences. In this paper, it is proposed to promote the sustainable management of forest resources using a method coming from the Environmental Management Accounting discipline. The method is Material Flow Cost Accounting, which assists managers to recognize material and energy inefficiencies in production processes and create cost savings for the organization. Through a study of the methodology and using forestry examples, it is shown that Material Flow Cost Accounting can be a useful tool for forest managers, either in Public Forest Service, or other forestry organizations.
\end{abstract}

\section{Keywords}

Environmental Management Accounting, Public Forest Service, Sustainable Management of Forest Resources, Emissions, Energy Efficiency

\section{Introduction}

Forestry supplies society with numerous products and services, either tradeable, or not tradeable in the markets, but with significant value for the well-being of people. Forest science helps forest organizations or Public Forest Service to provide these products in an economically viable way through a sustainable management of forest resources. Nevertheless, it was in this science that sustainability was described for the first time more than 300 years ago by von Carlowitz (1713). The concept of timber sustained 
yield by von Carlowitz has evolved through the years to an integrated approach of sustainability, which promotes the wise use of natural resources (Pearce \& Atkinson, 1993). Achieving such a goal means that forest organizations evaluate the whole production process of the products and services for their negative and positive social and environmental impacts.

Several methodologies have been proposed for measuring the negative impacts of production processes in operations and organizations. Methodologies like Life Cycle Costing (LCC), Life Cycle Assessment (LCA), Material Flow Analysis (MFA), and Environmental Management Accounting (EMA) give an insight to the material and energy flows and their impact on sustainability. Material Flow Cost Accounting (MFCA) is a method under the umbrella of EMA, specialized in quantifying and costing these flows, allocating them to the responsible products and services and providing opportunities for the minimization of negative impact and for cost savings for the organization (Jasch, 2009). The relative new ISO 14051 has helped the application of MFCA by standardizing the existing knowledge (ISO, 2011). According to Kokubu \& Kitada (2015), the ISO 14051 standard resulted because of the popularity of the method in Japan's industry in the 00s.

EMA has been proposed by Papaspyropoulos et al. (2012) and Houdet and Germaneau (2014) for accounting for impacts on environment, biodiversity and ecosystem services and they called for a standardization of the data collection to help organizations use the methodology. LCA and MFA have been used in the forestry sector for the understanding of the carbon balance between emissions and storage of forest management regimes (Routa et al., 2012; Sonne, 2006; Buonocore et al., 2014; Pyörälä et al., 2012; Päivinen et al., 2012). The last two methods treat emissions as outputs of the production process and give the opportunity to compare this output to the desired products. However, they do not relate these emissions to monetary units, thus no financial inefficiencies are recognized. That is, no incentives for cost savings are provided by these methodologies. MFCA, on the other hand, is a step further EMA and recognizes the material and monetary flows for the desired outputs, but also for the undesired ones, which are characterized as non-product outputs, or simply wastes. This method arises from the industry sector and there are very few applications in other sectors for tracking their inefficiencies (Christ \& Burritt, 2015a). Schaltegger and Zvezdov (2015) believe that the current applications of MFCA are quite few compared to its potential application, while Christ and Burritt (2015b) believe that the diffusion of MFCA in the next years will increase.

The method seems to lack of application on primary products, such as forestry products, therefore, the present paper researches the current trends on MFCA, and it relates it to forestry products and services. Through an MFCA study and using forestry examples, it is shown that MFCA can be a useful tool for forest managers, either in Public Forest Service, or other forestry organizations. Thus, the research question can be placed as follows: how can forestry sector adapt MFCA and help forest managers improve decision making and produce forest products sustainably? 


\section{The Methodology}

\subsection{Conventional vs Material Flow Cost Accounting}

Traditionally in industry and other sectors conventional cost accounting systems have been used, either for measuring the historical cost of the production process, or for budgeting reasons. Cost accounting methods measure direct and indirect costs and assign them to cost centers and cost carriers (Hansen et al., 2007). In this system, many hidden environmental costs (like energy and water costs) are treated as overheads, and are all allocated to the desired product output. However, such a practice "punishes" the product with costs that are simply wastes. Therefore, methods like Environmental Cost Accounting (ECA) have been suggested for revealing the true costs of wastes (Jasch, 2009).

Material Flow Cost Accounting is one of the approaches for performing an ECA analysis (Papaspyropoulos et al., 2012; Christ \& Burritt, 2015b) and it is included in the more general Environmental Management Accounting framework (Burritt et al., 2002) and discipline (Schaltegger et al., 2013). The method was presented firstly in Germany in late 90s (Wagner, 2015), it origins from the manufacturing sector and it has been used mainly in Germany and Japan (Nakajima, 2006; Kokubu \& Kitada, 2015; Schmidt et al., 2015). It can be also used in the service sector (Jasch, 2009) and it has been proved that it can be a useful tool to partially augment the accountability of the non-profit sector (Papaspyropoulos et al., 2012). It is based on the input-output analysis aspect of sustainability accounting and the principle "what goes in must come out" (Lamberton, 2005). According to Rieckhof et al. (2015), MFCA is defined by ISO 14051:2011 as "tool for quantifying the flows and stocks of materials in processes or production lines in both physical and monetary units". ISO (2011) describes MFCA as a method that is applicable to any organization that uses materials and energy, regardless of their products or services.

Schmidt et al. (2015) refer that MFCA is conducted in three steps; the flow structure modeling, the quantification of flows and its cost appraisal. The first step includes the determination of system boundaries and the time period of the assessment, and the second the quantification of materials and all the outputs and non-product outputs. According to Jasch (2009) material inputs are the a) raw and auxiliary materials, b) the merchandise and packaging, c) the operating materials, d) energy and e) water that enter an organization. Outputs are a) the finished goods, b) services, c) by-products, d) emissions or e) waste. Non-product output is any output which does not leave the organization as a manufactured physical product. The third step, cost appraisal, estimates: material costs, which are the only direct costs of the process; energy costs, which refer to the energy entered in the production process; waste management costs, which are the costs for handling waste and emissions; and system costs, which represent labor costs and depreciation (Schmidt et al., 2015). Indices are used to allocate these costs to the product and the non-product outputs (i.e. percentage of material inputs in the final product). However, the waste management costs are allocated exclusively to the nonproduct output (ISO, 2011). 
Table 1 shows the basic concept behind MFCA. Conventional cost accounting (CCA) is compared to MFCA, when the same inputs are used. In CCA, all the costs are allocated to the product output, although one third of the materials used become waste. In this way, managers are not able to see the material and cost losses, and the consecutive environmental degradation. By using MFCA, a cost is allocated to the waste that is produced by the production process; additionally, there is a new cost which increases the production cost, the waste management cost, which is allocated only to the wastes. With MFCA, managers are able to manage the waste, reduce it, recycle it, or sell it as an input in other production process (Wan et al., 2015); thus, saving cost for the organization and reducing the resource use which affects environmental quality. The information about these costs can be derived from the annual expenditure accounts, refer to the same fiscal year, and under a usual cost accounting method (like activity based costing) can be assigned to cost categories, cost centers and cost carriers (Jasch, 2009).

\subsection{Environmental Performance Indicators}

Research has shown that the application of a successful Environmental Management Accounting system demands the establishment and measurement of several Environmental Performance Indicators (EPI) relevant to the production process (Jasch, 2009; Herzig et al., 2012; Papaspyropoulos et al., 2012). Jasch (2009) refers that the existence of an EPI system within an organization is useful for revealing opportunities for the optimization of the production process, for reducing the production cost and the relevant wastes, and for complying with several environmental management standards, e.g. ISO14001, or ISO14051 (MFCA). The systematic collection of EPI by an environmental statistics department is crucial for applying MFCA. These indicators should be focused on revealing the wastes (non-product outputs) of the production process. Jasch (2009) divides the main EPI in i) consumption/eco-intensity, ii) eco-efficiency, and iii) percentage distribution indicators. These types of EPI may be further divided in absolute and relative indicators. For example, an absolute eco-intensity indicator in forestry can be the $\mathrm{CO}_{2}$ emitted through logging operations, while $\mathrm{CO}_{2} / \mathrm{m}^{3}$ of timber can be the

Table 1. Comparison of conventional cost accounting and material flow cost accounting.

\begin{tabular}{ccc}
\hline \multirow{2}{*}{ Cost category } & \multicolumn{2}{c}{ Cost Accounting method } \\
\cline { 2 - 3 } & Conventional & Material Flow \\
\hline Sales & $15,000 €$ & $15,000 €$ \\
Production cost & $\mathbf{4 , 5 0 0 €}$ & $\mathbf{3 , 0 0 0 €}$ \\
Material loss cost & - & $\mathbf{1 , 5 0 0 €}$ \\
Gross profit & $10,500 €$ & $10,500 €$ \\
Other expenses & $8,000 €$ & $8,000 €$ \\
Operating profit & $2,500 €$ & $2,500 €$ \\
\hline
\end{tabular}

a. Source: ISO (2011), adapted by the Authors. 
relative corresponding one. An absolute eco-efficiency indicator in forestry could be the cost of producing the non-product outputs (waste), while this cost $/ \mathrm{m}^{3}$ of timber could be the relative counterpart. A percentage distribution indicator can be the number of the survived birds ten days after a release in a natural ecosystem, compared to the total released birds.

Papaspyropoulos et al. (2012) suggested the inclusion of indicators which show a positive impact of an organization on the environment. Thus, positive undesired outputs may be produced, such as $\mathrm{CO}_{2}$ sequestration through necessary plantations (e.g. for offering cover and food to wildlife).

\section{Forest Products and Services and Their Non-Product Outputs}

The present research focuses on timber production and the quarry species to discuss possible analogues of MFCA framework for forestry products. In terms of timber production, two undesired products are considered (emissions from energy and rotten wood), and one positive non-product output (forest biomass residuals). In terms of quarry species, one type of waste is discussed, the birds that die few days after the release in the natural environment, without fulfilling the objective of their raising. The above are discussed focusing on the practices of Public Forest Service in Greece, which is the biggest producer of these desired and undesired outputs. Some data are used from the publicly available "Activity Reports" (Ministry of Environment, 2013), published annually by the organization informing stakeholders about Public Forest Service operation.

\subsection{The Non-Product Outputs of Timber Production}

As mentioned earlier, previous research has estimated the negative environmental impact of forest management practices. The impact occurs due to the use of energy for logging, and other silviculture operations. During the logging of a natural tree stand, energy is used for the final felling of timber, and its extraction. If a plantation is cut, it should be taken into account that energy has been also used for soil scarification, cleaning and fertilizing (González-García et al., 2009; Dias \& Arrojia, 2012; GonzálezGarcía et al., 2014). For the objective of the present research, the simple scenario of a natural stand is discussed, where the only impacts come from logging. In such a case, the production process for producing $1 \mathrm{~m}^{3}$ of timber under bark (ub) is as shown in Figure 1.

The material input in this process is the fuel for the logging and the tree that is being cut. The tree is considered here as a material input, because, from the whole tree, one part becomes, after logging, usable product (for example roundwood and fuelwood). It is estimated there is a $10 \%$ - $30 \%$ difference between the volume of the tradeable timber after logging and the volume of the whole tree that is being cut, which additionally includes the branches and other non-tradeable parts of the tree (Matis, 2004). Thus, in such a process, there is an output which at least in countries like Greece, according to the Reports published by the Public Forest Service, becomes residual and is not included 


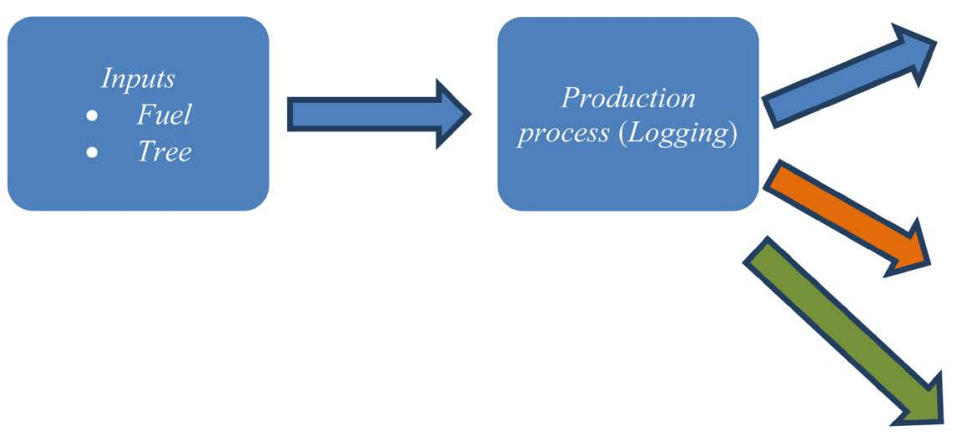

Figure 1. Logging operation and its outputs.

in the final product. This product is considered in this research as positive output because it is necessary for the ecosystem due to its organic matter and it is estimated as the $20 \%$ of the tree volume (for the present application $1.25 \mathrm{~m}^{3}$ of tree produce $1 \mathrm{~m}^{3}$ of wood ub).

Finally, after the process, an undesired product can exist if the Public Forest Service does not manage to sell the produced timber, occasions that were quite often in Greece due to the low quality of roundwood. This quantity may become rotten wood and can be considered as an unsold product remaining in the "warehouse" of the forest, which is the roadside where the timber has been transferred after the logging. If this quantity is managed additionally, it produces waste management costs. However, it can offer earnings for the Forest Service, together with the forest biomass residuals, if the organization manage to sell them and be included in another production process, i.e. production of wood chips (Wan et al., 2015). Finally, waste management costs may occur if a regulation is set by the government for the $\mathrm{CO}_{2}$ emissions, and the forest service has to oblige with it by offsetting the amount. All the above costs, material, energy and waste management costs, bear system costs, which refer to labor and depreciation costs.

As it may be seen in Table 2, MFCA can help forest managers to understand that the desired output of the process $\left(1 \mathrm{~m}^{3}\right.$ of wood $\mathrm{ub}$ ) does not really bear all the cost of the production process, but less than $80 \%$ of the total cost. Allocating all the cost to the desired output, as conventional cost accounting implies, does not show potential for cost savings or profit making by the more than $20 \%$ cost of the undesired output[the exact percentage is $\left.\left(0.2^{\star}(\mathrm{A}+\mathrm{B})+\mathrm{C}\right)^{\star} 100 /(\mathrm{A}+\mathrm{B}+\mathrm{C})\right]$. This percentage can offer cost savings if, for example, the Forest Service manages to reduce the fuel quantities needed for producing $1 \mathrm{~m}^{3} \mathrm{ub}$. Additionally, this resource efficiency is positive for the environment since there is less fossil fuel combustion and less $\mathrm{CO}_{2}$ emissions. Finally, this more than $20 \%$ can offer profit earnings if forest managers increase the wood quantity that is utilized as desired output. It has to be mentioned here, that in this example, the tree as an input was chosen to be free of cost if the land is public and the Public Forest Service 
Table 2. Material flow cost accounting example for producing $1 \mathrm{~m}^{3}$ of wood ub.

\begin{tabular}{cccccccc}
\hline & \multicolumn{5}{c}{ Material Flow Cost Accounting cost categories } & CCA \\
\cline { 2 - 7 } $\begin{array}{c}\text { Cost } \\
\text { category }\end{array}$ & Volume or Mass & $\begin{array}{c}\text { Material } \\
\text { costs }\end{array}$ & $\begin{array}{c}\text { Energy } \\
\text { costs }\end{array}$ & $\begin{array}{c}\text { System } \\
\text { costs }\end{array}$ & $\begin{array}{c}\text { Waste } \\
\text { management } \\
\text { costs }\end{array}$ & Total costs & Total costs \\
\hline $\begin{array}{c}\text { Total } \\
\text { inputs }\end{array}$ & $\begin{array}{c}1.25 \mathrm{~m}^{3} \\
\text { (raw timber } \\
\text { with bark, i.e. the tree) }\end{array}$ & 0 & $\mathrm{~A}$ & $\mathrm{~B}$ & $\mathrm{C}$ & $\mathrm{A}+\mathrm{B}+\mathrm{C}$ & $\mathrm{A}+\mathrm{B}+\mathrm{C}$ \\
Product & $\begin{array}{c}1 \mathrm{~m}^{3} \text { of wood ub } \\
0.25 \mathrm{~m}^{3} \text { of wood } \\
\text { residuals }+ \\
\text { unsold timber }\end{array}$ & 0 & $0.8^{*} \mathrm{~A}$ & $0.8^{*} \mathrm{~B}$ & 0 & $0.8^{*}(\mathrm{~A}+\mathrm{B})$ & $\mathrm{A}+\mathrm{B}+\mathrm{C}$ \\
$\begin{array}{c}\text { Material } \\
\text { loss }\end{array}$ & 0 & $0.2^{*} \mathrm{~A}$ & $0.2^{*} \mathrm{~B}$ & $\mathrm{C}$ & $0.2^{*}(\mathrm{~A}+\mathrm{B})+\mathrm{C}$ & 0 \\
$\begin{array}{c}\text { Total } \\
\text { outputs }\end{array}$ & \begin{tabular}{c}
$1.25 \mathrm{~m}^{3}$ of wood \\
\hline
\end{tabular} & 0 & $\mathrm{~A}$ & $\mathrm{~B}$ & $\mathrm{C}$ & $\mathrm{A}+\mathrm{B}+\mathrm{C}$ & $\mathrm{A}+\mathrm{B}+\mathrm{C}$ \\
\hline
\end{tabular}

did not pay for managing it. The last column of Table 2 shows how these costs would have been treated by CCA. No material loss costs would have been measured and all the cost $(A+B+C)$ would have been allocated to the $1.25 \mathrm{~m}^{3}$ of wood. Thus, in CCA the cost of producing $1 \mathrm{~m}^{3}$ of wood $\mathrm{ub}$ is $\mathrm{A}+\mathrm{B}+\mathrm{C}$, while in MFCA this cost is $0.8^{\star}(\mathrm{A}+\mathrm{B})$, that is $\mathrm{C}+0.2^{*}(\mathrm{~A}+\mathrm{B})$ less.

For helping the application of MFCA in this production process and for monitoring reasons, the Forest Service should construct a system of EPI which will include the following consumption/eco-intensity indicators: the measurement in physical amounts of the Energy (fuel, diesel) used for logging (total and per $\mathrm{m}^{3} \mathrm{ub}$ ), the emissions to air (total $\mathrm{CO}_{2}$ and per $\mathrm{m}^{3}$ due to logging), $\mathrm{m}^{3}$ of timber unsold. Eco-efficiency indicators are needed, too, for example the cost of energy per $\mathrm{m}^{3}$ of timber, and percentage distribution indicators like the percentage of the tree being utilized as desired product (efficiency of timber production).

\subsection{The Non-Product Output of Quarry Species Rearing}

In Greece, the Public Forest Service operates a number of public farms for releasing reasons. Mainly galliforms are artificially and hares are intensively reared in cages (Sokos et al., 2008; Sokos et al., 2015). The objectives of the releases are the augmentation of hunted populations, "put and take" in public shooting preserves and population establishment or augmentation of threatened species (Sokos et al., 2008). Several studies, however, have proved that this technique is inadequate for the objectives that it tries to serve. For example, it has been estimated that more than $50 \%$ of artificially reared galliforms die within few weeks after release (Parish \& Sotherton, 2007; Sokos et al., 2008; Sokos et al., 2016). The same situation occurs with reared hares. Researchers have found that $60 \%-90 \%$ of the intensively reared hares died in thirty days after release due to predation (Angelici et al., 2000; Sokos et al., 2015). Thus, the desired output of reared birds becomes a waste within few days after release. MFCA here can play a significant role by showing the potential cost savings. 
The 2010 Activity Report (Ministry of Environment, 2013) shows that for the production of 100 birds in the Greek Public Forest Service farms almost $700 €$ are required. Figure 2 shows that by using CCA forest managers understand that 100 birds are released and each bird costs $7 €$. However, the truth is that only for example $10 \%$ of these birds manage to survive, or are harvested by the hunters. The other $90 \%$ die within a few days. By using MFCA, the forest managers can understand that there are birds which become waste (non-product output), and this bears a material, system and energy cost for the organization, which can be $630 €$ (a 90\% loss) and proves the inefficiency of the technique. In this case, there are no waste management costs, since the dead birds are not collected.

Thus, consumption/eco-intensity EPI that could help the organization here for the application of MFCA could be the energy used for the production of released species (total and per individual), and other materials used (i.e. total feed and per individual), while a significant distribution indicator would be the percentage of established population compared to the released population.

\section{Framework for Using MFCA in Forestry}

In Figure 3 the proposed framework for applying Material Flow Cost Accounting in Forestry is shown. The framework is summarized in seven steps, which include the three steps discussed by Schmidt et al. (2015) for the application of MFCA.

In Step 1 the boundaries for the application of MFCA have to be found. Forest management includes numerous cost centers like logging of natural stands, forest plant nurseries, quarry species rearing, public hunting preserves, forest engineering works. Setting the boundaries of each cost center and its production process can simplify the application of MFCA. Seeing all the forest operations as one process may be more difficult for the utilization of MFCA, though not negative. In Step 2 the flow structure has to be modelled. This includes tracing where and when the material and energy inputs are used, and when and what desired and undesired outputs are produced. When these

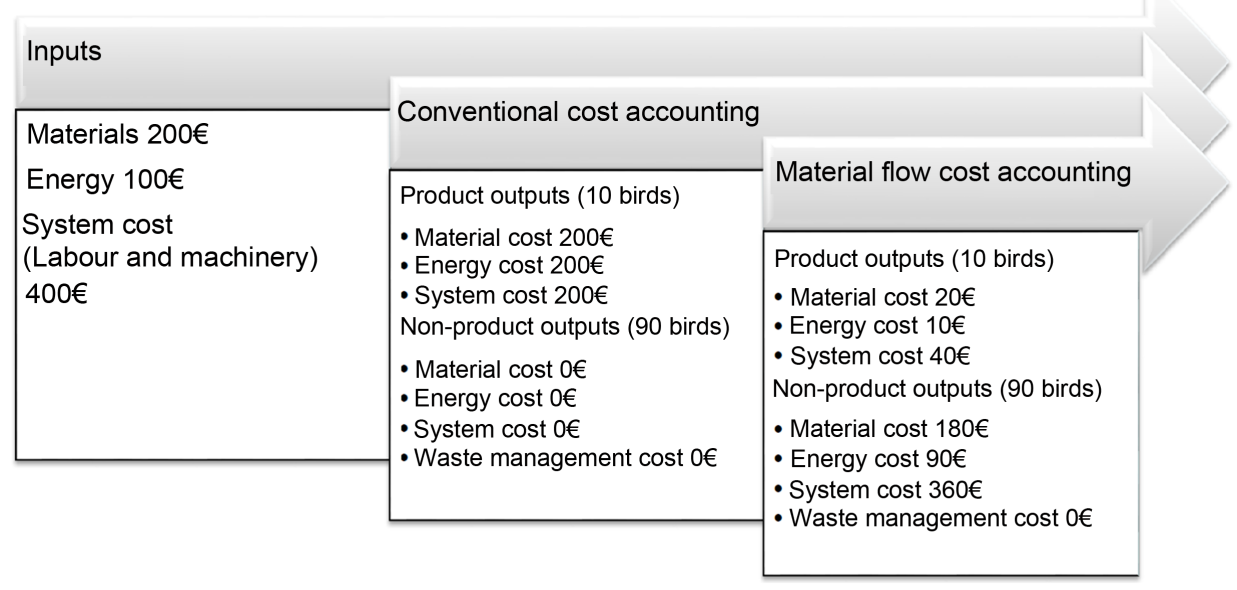

Figure 2. CCA and MFCA for quarry species rearing in Forest Service public farms. 


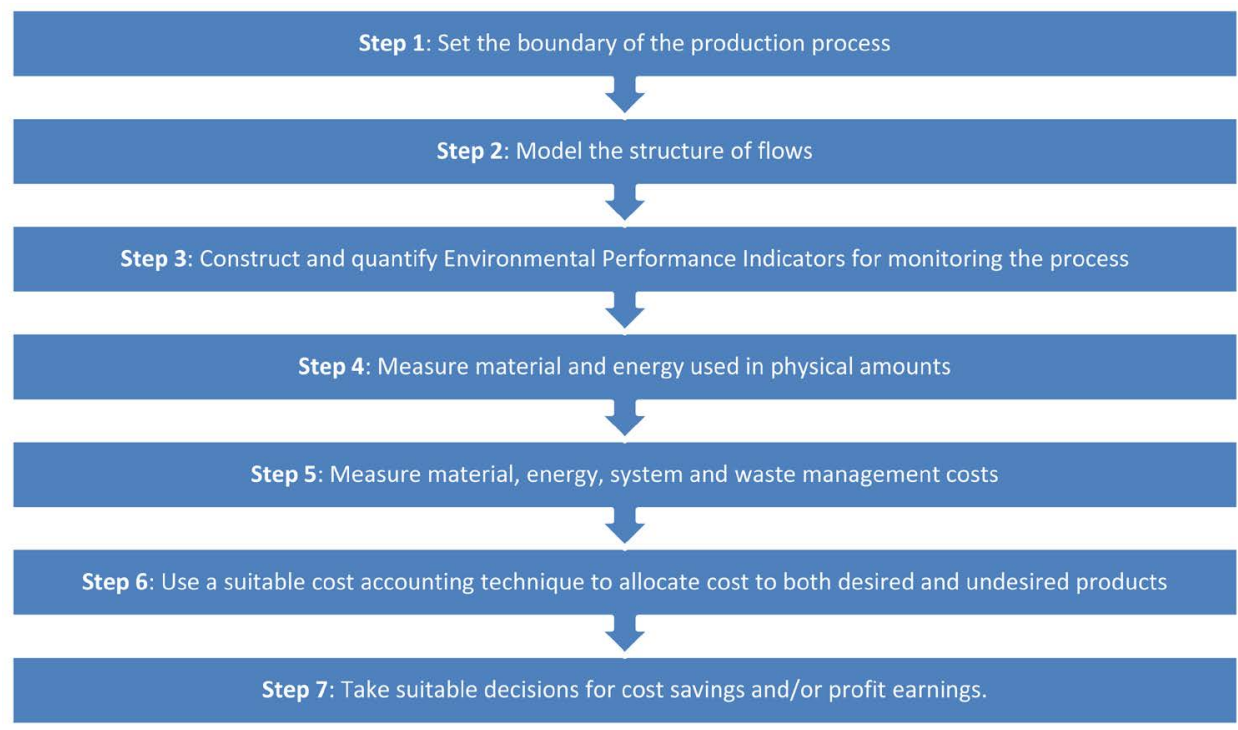

Figure 3. Proposed framework for applying MFCA in forestry.

flows are understood, constructing an EPI system is crucial for monitoring the process.

This will take place in Step 3. By using consumption/eco-intensity indicators, it will help forest managers in Step 4 to quantify and measure in physical amounts the materials and energy used in the process. The use of eco-efficiency indicators will help measure the four cost categories of Step 5. The distribution indicators will help both Step 4 and Step 5. In Step 6 and by using a cost accounting method like Activity Based Costing ( $\mathrm{ABC}$ ), the forest managers will be able to understand both the cost of desired and undesired outputs. The costing of wastes and other non-product outputs will be visible for the first time and in Step 7 the management department can take decisions for cost savings and/or profit earnings by managing the wastes.

\section{Discussion and Conclusions}

In this paper it is proposed to enhance the sustainability in forestry by accounting for the production cost of undesired outputs, like $\mathrm{CO}_{2}$ emissions, and wood residuals from logging operations. The method of Material Flow Cost Accounting, coming from the Environmental Management Accounting discipline, is able to unveil inefficiencies in production processes and provide opportunities for cost savings for the organization. Forestry science is a pioneer in sustainability and can lead by example in managing the negative impacts of its operation and protecting natural environment. The paper provided two possible examples of MFCA application which showed that by accounting for negative and positive (undesired or non-product) outputs, a forestry organization like Public Forest Service in Greece can understand the inefficiencies of timber production and quarry species rearing, their environmental impacts, their impact on the operation cost, and their impact on natural environment. The crucial issue for forest managers is to understand the principle "what goes in must go out", that is the mass (volume) of inputs has to be the same as the mass (volume) of outputs. In forest operations this may 
sometime be difficult to understand; for example the tree as an input of a logging process may seem weird, but it is believed that by following the framework for MFCA application presented in Section 4, the managers will understand how to construct a reliable flow structure model.

The paper showed that by accounting for the undesired outputs the foresters may construct indicators for better monitoring the relationship between product output and non-product output and may locate where these quantities mostly occur, the reasons behind this situation, and the ways to avoid it. Of course more applications in other countries and in other Forestry subsectors could give an insight if MFCA can be widely applicable. The present research showed that in a country like Greece, where there is a lack of full utilization of the products that a tree can give, MFCA is reliable in presenting the inefficiencies of logging operations. The same situation occurs in the controversial issue of wildlife species release as, in Greece and other countries, there is a significant number of individuals which become "waste" (die from predation) just few days after release. Other examples of MFCA application from more developed countries in forestry issues, for example countries from Scandinavia or North America, where the forests are managed mainly for timber, would be valuable in the discussion.

In general, the advantages of using MFCA in forestry could be the resource efficiency, the cost savings, the better utilization of the production process, and the greening of forestry sector, a sector with an environmental mandate. On the other hand, the disadvantages can be the cost of creating an EPI system and monitoring forestry statistics, something that, especially in primary sectors is usually difficult and time consuming to create.

Concluding, the present research showed that:

- MFCA can be an effective tool in forestry for the improvement of production process.

- Sustainability can be enhanced due to resource efficiency offered by applying MFCA.

- Monitoring the production process with MFCA can create cost savings and new usable products.

- An effective statistical collection of environmental indicators is needed for the better application of MFCA.

\section{Acknowledgements}

In the memory of Professor Athanassios Christodoulou who passed away during the research.

The first author would like to thank the IKY Fellowships of Excellence for Postgraduate Studies in Greece-Siemens Program for funding him for this research.

\section{References}

Angelici, F. M., Riga, F., Boitani, L., \& Luiselli, L. (2000). Fate of Captive-Reared Brown Hares (Lepus europaeus) Released at a Mountain Site in Central Italy. Wildlife Biology, 6, 173-178. 
Buonocore, E., Häyhä, T., Paletto, A., \& Franzese, P. P. (2014). Assessing Environmental Costs and Impacts of Forestry Activities: A Multi-Method Approach to Environmental Accounting. Ecological Modelling, 271, 10-20. http://dx.doi.org/10.1016/j.ecolmodel.2013.02.008

Burritt, R. L., Hahn, T., \& Schaltegger, S. (2002). Towards a Comprehensive Framework for Environmental Management Accounting. Links between Business Actors and Environmental Management Accounting Tools. Australian Accounting Review, 12, 39-50.

Christ, K. L., \& Burritt, R. L. (2015a). ISO 14051: A New Era for MFCA Implementation and Research. Revista de Contabilidad, 19, 1-9.

Christ, K. L., \& Burritt, R. L. (2015b). Material Flow Cost Accounting: A Review and Agenda for Future Research. Journal of Cleaner Production, 108, 1378-1389.

Dias, A. C., \& Arroja, L. (2012). Environmental impacts of eucalypt and maritime pine wood production in Portugal. Journal of Cleaner Production, 37, 368-376.

http://dx.doi.org/10.1016/j.jclepro.2012.07.056

González-García, S., Berg, S., Feijoo, G., \& Moreira, M. T. (2009). Environmental Impacts of Forest Production and Supply of Pulpwood: Spanish and Swedish Case Studies. The International Journal of Life Cycle Assessment, 14, 340-353. http://dx.doi.org/10.1007/s11367-009-0089-1

González-García, S., Dias, A. C., Feijoo, G., Moreira, M. T., \& Arroja, L. (2014). Divergences on the Environmental Impact Associated to the Production of Maritime Pine Wood in Europe: French and Portuguese Case Studies. Science of the Total Environment, 472, 324-337. http://dx.doi.org/10.1016/j.scitotenv.2013.11.034

Hansen, D. R., Mowen, M. M., \& Guan, L. (2007). Cost Management. Accounting \& Control $\sigma^{\text {th }}$ Edition. Mason, MI: South-Western Cengage Learning.

Herzig, C., Viere, T., Schaltegger, S., \& Burritt, R. L. (2012). Environmental Management Accounting: Case Studies of South-East Asian Companies. Oxon: Routledge.

Houdet, J., \& Germaneau, C. (2014). Accounting for Biodiversity and Ecosystem Services from an EMA Perspective. Towards a Standardised Biodiversity Footprint Methodology. In M. Jones (Ed.), Accounting for Biodiversity (pp. 52-80). Oxon: Routledge.

ISO (2011). ISO 14051:2011. Environmental Management. Material Flow Cost Accounting. General Framework. Geneva: ISO.

Jasch, Ch. (2009). Environmental and Material Flow Cost Accounting: Principles and Procedures. Berlin: Springer.

Kokubu, K., \& Kitada, H. (2015). Material Flow Cost Accounting and Existing Management Perspectives. Journal of Cleaner Production, 108, 1279-1288.

http://dx.doi.org/10.1016/j.jclepro.2014.08.037

Lamberton, G. (2005). Sustainability Accounting-A Brief History and Conceptual Framework. Accounting Forum, 29, 7-26.

http://dx.doi.org/10.1016/j.accfor.2004.11.001

Matis, K. (2004). Forest Biometry II. Thessaloniki: Pegasus. (In Greek)

Ministry of Environment (2013). Activity Report 2010. Athens.

Nakajima, M. (2006). The New Management Accounting Field Established by Material Flow Cost Accounting (MFCA). Kansai University Review of Business and Commerce, 8, 1-22.

Päivinen, R., Lindner, M., Rosén, K., \& Lexer, M. J. (2012). A Concept for Assessing Sustainability Impacts of Forestry-Wood Chains. European Journal of Forest Research, 131, 7-19. http://dx.doi.org/10.1007/s10342-010-0446-4 
Papaspyropoulos, K. G., Blioumis, V., Christodoulou, A. S., Birtsas, P. K., \& Skordas, K. E. (2012). Challenges in Implementing Environmental Management Accounting Tools: The Case of a Nonprofit Forestry Organization. Journal of Cleaner Production, 29-30, 132-143.

http://dx.doi.org/10.1016/j.jclepro.2012.02.004

Parish, D. M. B., \& Sotherton, N. W. (2007). The Fate of Released Captive-Reared Grey Partridges Perdix perdix: Implications for Reintroduction Programmes. Wildlife Biology, 13, 140149. http://dx.doi.org/10.2981/0909-6396(2007)13[140:TFORCG]2.0.CO;2

Pearce, D. W., \& Atkinson, G. D. (1993). Capital Theory and the Measurement of Sustainable Development: An Indicator of "Weak" Sustainability. Ecological Economics, 8, 103-108. http://dx.doi.org/10.1016/0921-8009(93)90039-9

Pyörälä, P., Kellomäki, S., \& Peltola, H. (2012). Effects of Management on Biomass Production in Norway Spruce Stands and Carbon Balance of Bioenergy Use. Forest Ecology and Management, 275, 87-97. http://dx.doi.org/10.1016/j.foreco.2012.02.037

Rieckhof, R., Bergmann, A., \& Guenther, E. (2015). Interrelating Material Flow Cost Accounting with Management Control Systems to Introduce Resource Efficiency into Strategy. Journal of Cleaner Production, 108, 1262-1278. http://dx.doi.org/10.1016/j.jclepro.2014.10.040

Routa, J., Kellomäki, S., \& Peltola, H. (2012). Impacts of Intensive Management and Landscape Structure on Timber and Energy Wood Production and $\mathrm{Net} \mathrm{CO}_{2}$ Emissions from Energy Wood Use of Norway Spruce. Bioenergy Research, 5, 106-123. http://dx.doi.org/10.1007/s12155-011-9115-9

Schaltegger, S., \& Zvezdov, D. (2015). Expanding Material Flow Cost Accounting. Framework, Review and Potentials. Journal of Cleaner Production, 108, 1333-1341. http://dx.doi.org/10.1016/j.jclepro.2014.08.040

Schaltegger, S., Gibassier, D., \& Zvezdov, D. (2013). Is Environmental Management Accounting a Discipline? A Bibliometric Literature Review. Meditari Accountancy Research, 21, 4-31. http://dx.doi.org/10.1108/MEDAR-12-2012-0039

Schmidt, A., Götze, U., \& Sygulla, R. (2015). Extending the Scope of Material Flow Cost Accounting-Methodical Refinements and Use Case. Journal of Cleaner Production, 108, 13201332. http://dx.doi.org/10.1016/j.jclepro.2014.10.039

Sokos, C. K., Birtsas, P. K., \& Tsachalidis, E. P. (2008). The Aims of Galliforms Release and Choice of Techniques. Wildlife Biology, 14, 412-422. http://dx.doi.org/10.2981/0909-6396-14.4.412

Sokos, C. K., Birtsas, P. K., Papaspyropoulos, K. G., \& Sánchez-García, C. (2016). Professionalism in Wildlife Management: The Case of Gallifoms Releases in Hellas. Open Journal of Forestry, 6, 51-58. http://dx.doi.org/10.4236/ojf.2016.62005

Sokos, C., Birtsas, P., Papaspyropoulos, K. G., Giannakopoulos, A., Athanasiou, L. V., Manolakou, K., Spyrou, V., \& Billinis, C. (2015). Conservation Considerations for a Management Measure: An Integrated Approach to Hare Rearing and Release. Environmental Management, 55, 19-30. http://dx.doi.org/10.1007/s00267-014-0388-6

Sonne, E. (2006). Greenhouse Gas Emissions from Forestry Operations. Journal of Environmental Quality, 35, 1439-1450. http://dx.doi.org/10.2134/jeq2005.0159

Von Carlowitz, H. C. (1713). Sylvicultura Oeconomica. Leipzig.

Wagner, B. (2015). A Report on the Origins of Material Flow Cost Accounting (MFCA) Research Activities. Journal of Cleaner Production, 108, 1255-1261. http://dx.doi.org/10.1016/j.jclepro.2015.10.020

Wan, Y. K., Ng, R. T., Ng, D. K., \& Tan, R. R. (2015). Material Flow Cost Accounting (MFCA)Based Approach for Prioritisation of Waste Recovery. Journal of Cleaner Production, 107, 602614. http://dx.doi.org/10.1016/j.jclepro.2015.05.024 


\section{Abbreviation List}

CCA: Conventional Cost Accounting

ECA: Environmental Cost Accounting

EMA: Environmental Management Accounting

EPI: Environmental Performance Indicators

ISO: International Organization for Standardization

LCA: Life Cycle Assessement

LCC: Life Cycle Costing

MFA: Material Flow Analysis

MFCA: Material Flow Cost Accounting

Submit or recommend next manuscript to SCIRP and we will provide best service for you:

Accepting pre-submission inquiries through Email, Facebook, LinkedIn, Twitter, etc.

A wide selection of journals (inclusive of 9 subjects, more than 200 journals)

Providing 24-hour high-quality service

User-friendly online submission system

Fair and swift peer-review system

Efficient typesetting and proofreading procedure

Display of the result of downloads and visits, as well as the number of cited articles

Maximum dissemination of your research work

Submit your manuscript at: http://papersubmission.scirp.org/ 